\title{
HUBUNGAN KADAR ASAM URAT DENGAN KADAR KREATININ PADA PASIEN GAGAL GINJAL KRONIK YANG MENJALANI HEMODIALISA DI RUMAH SAKIT PERTAMINA BINTANG AMIN BANDAR LAMPUNG TAHUN 2016
}

\author{
Muhammad Nur ${ }^{1}$, Anggunan², Pradita Defi Wulandari²
}

${ }^{1}$ Departemen patologi Klinik, Rumah Abdul Moeloek Lampung

${ }^{2}$ Prodi Pendidikan Dokter Fakultas Kedokteran, Universitas Malahayati

\section{ABSTRAK}

Riset Kesehatan Dasar (Riskesdas) tahun 2013 melaporkan prevalensi penyakit gagal ginjal kronis (GGK) berdasarkan diagnosis dokter di Indonesia sebesar $0,2 \%$. Penurunan fungsi ginjal pada pasien GGK akan menghasilkan berbagai macam komplikasi salah satunya adalah hiperurisemia, Ginjal mengalami gangguan untuk memfiltrasi darah sehingga zat sisa metabolisme tubuh seperti urea, asam urat dan kreatinin tidak dapat diekskresikan.Tujuan Penelitian adalahUntuk mengetahui hubungan Kadar Asam Urat dengan Kadar Kreatinin pada pasien gagal ginjal kronik yang menjalani hemodialisa di Rumah Sakit Pertamina Bintang Amin Bandar Lampung Tahun 2016.Penelitian ini menggunakan metode analitik dengan pendekatan "cross sectional.". Populasi dalam penelitian ini adalah pada pasien gagal ginjal kronik yang menjalani hemodialisa di Rumah Sakit Pertamina Bintang Amin Bandar Lampung berjumlah 55 orang. Sampel total populasi. Pengumpulan data dilakukan dengan uji Laboratorium. Analisa data yang digunakan adalah chi square. Hasil analisis didapatkan rata-rata Kadar Kreatinin pada pasien gagal ginjal kronik yang menjalani hemodialisa adalah $2,85 \mathrm{mg} / \mathrm{dl}$, dengan SD 0,89 mg/dl. Rata-rata kadar asam urat pada pasien gagal ginjal kronik yang menjalani hemodialisa adalah $7,49 \mathrm{mg} / \mathrm{dl}$, dengan SD $1,34 \mathrm{mg} / \mathrm{dl}$. Tidak ada hubungan Kadar Asam Urat dengan Kadar Kreatinin pada pasien gagal ginjal kronik yang menjalani hemodialisa di Rumah Sakit Pertamina Bintang Amin Bandar Lampung Tahun 2016.

Kata Kunci : Asam Urat, Kreatinin, Pasien Gagal Ginjal Kronik

\section{Latar Belakang}

Gagal ginjal kronik merupakan

salah satu penyakit yang berpotensi fatal dan dapat menyebabkan pasien mengalami penurunan kualitas hidup baik kecacatan maupun kematian. Pada gagal ginjal kronik (GGK) umumnya akan terjadi penurunan massa ginjal yang dapat mengakibatkan hipertrofi struktural dan fungsional dari nefron yang masih tersisa, hal tersebut merupakan upaya kompensasi yang dilakukan oleh ginjal. Pasien yang mengalami gangguan fungsi ginjal, pada umumnya mempunyai komposisi atau volume urin yang tidak normal misalnya adanya sel darah merah atau sejumlah protein di dalam urin (Russell and Norman, 2008). Definisi lain dari GGK adalah terjadinya penurunan nilai GFR $<60 \mathrm{ml} /$ menit/1.73 $\mathrm{m} 2$ selama 3 bulan atau lebih, dengan atau tanpa kerusakan ginjal (NKF, 2002).
Ginjal merupakan organ yang berfungsi untuk mempertahankan stabilitas volume, komposisi elektrolit, dan osmolaritas cairan ekstraseluler. Salah satu fungsi penting ginjal lainnya adalah untuk mengekskresikan produkproduk akhir/ sisa metabolisme tubuh, misalnya urea, asam urat, dan kreatinin. Apabila sisa metabolisme tubuh tersebut dibiarkan menumpuk, zat tersebut bisa menjadi racun bagi tubuh, terutama bagi otak. (Sherwood, 2012).

Pada pasien dengan penyakit ginjal kronik, ginjal tidak dapat berfungsi dengan baik. Ginjal mengalami gangguan untuk memfiltrasi darah sehingga zat sisa metabolisme tubuh seperti urea, asam urat dan kreatinin tidak dapat diekskresikan. Riset Kesehatan Dasar (Riskesdas) tahun 2013 melaporkan prevalensi penyakit gagal ginjal kronis (GGK) berdasarkan diagnosis dokter di Indonesia sebesar $0,2 \%$. Riskesdas juga melaporkan 
prevalensi gagal ginjal kronis terbesar terdapat pada pasien berusia $\geq 75$ tahun, yaitu sebesar $0,6 \%$. Prevalensi gagal ginjal kronis di Sumatera Utara dilaporkan mencapai $0.2 \%$. Berdasarkan jenis kelamin, Riskesdas (2013) melaporkan prevalensi gagal ginjal kronis pada pria di Indonesia sebesar $0,3 \%$ dan pada wanita di Indonesia sebesar 0,2\%. Data prevalensi di atas menunjukkan bahwa penyakit gagal ginjal kronis telah menjadi permasalahan utama dalam kesehatan masyarakat pada umumnya (National Kidney Foundation, 2002).

Penurunan fungsi ginjal pada pasien GGK akan menghasilkan berbagai macam komplikasi salah satunya adalah hiperurisemia. Hiperurisemia adalah ketidakseimbangan antara produksi dan sekresi dari asam urat. Ketidak seimbangan antara produksi dan sekresi akan menimbulkan hipersaturasi asam urat yaitu kelarutan asam urat dalam serum melebihi ambang batasnya, sehingga merangsang timbunan urat dalam bentuk garamnya terutama monosodium urat di berbagai tempat/jaringan (Wortman, 2009).

Kondisi hiperurisimia merupakan suatu faktor resiko timbulnya penyakit ginjal. Berdasarkan penelitian, pasien dengan kadar asam urat serum sekitar $7,0-8,9 \mathrm{mg} / \mathrm{dl}$ akan memiliki resiko dua kali lebih besar mengalami penyakit ginjal, sedangkan peningkatan kadar asam urat serum $\geq 9,0 \mathrm{mg} / \mathrm{dl}$ pasien mempunyai resiko menderita penyakit ginjal meningkat menjadi tiga kali lipat. Peningkatan kadar asam urat dalam serum dapat membentuk kristal - kristal asam urat di ginjal dan dapat mengendap di dalam insterstitium medular ginjal, tubulus atau sistem pengumpul yang akhirnya akan menyebabkan gagal ginjal akut maupun kronik. Penyakit ginjal yang dapat ditimbulkan dari kondisi hiperurisemia antara lain : nefropati asam urat akut, nefrolitiasis asam urat, nefropati urat kronik (Wortman, 2009; Obemayr, 2008).

Nefropati asam urat akut disebabkan oleh pengendapan kristal asam urat dalam tubulus ginjal yang menyebabkan obstruksi dan berkembangnya gagal ginjal akut.
Nefrolitiasis didefinisikan sebagai pembentukan batu di dalam ginjal oleh karena adanya pengendapan dari beberapa jenis senyawa, satu diantaranya adalah asam urat. Nefrolitiasis asam urat sering terjadi pada pasien hiperurisemia dan pasien dengan keganasan pergantian sel yang cepat (misalnya leukemia). Kondisi nefrolitiasis ini terjadi ketika kadar asam urat dalam serum diatas $10 \mathrm{mg} / \mathrm{dl}$ (Wilson and Price, 2005). Sedangkan nefropati urat kronik, atau nefropati gout akan terjadi pada pasien gout dan hiperurisemia yang berlarut - larut ( $>7$ mg/dl) (Wortman, 2009).

Tahapan gagal ginjal kronik dapat dibagi menurut beberapa cara, antara lain dengan memperhatikan faal ginjal yang masih tersisa. Bila faal ginjal yang masih tersisa sudah minimal dan usahausaha pengobatan konservatif berupa diet, pembatasan minum, obat-obatan dan lain-lain tidak memberi pertolongan yang diharapkan lagi, keadaan tersebut diberi nama gagal ginjal terminal (GGT). Pada stadium ini terdapat akumulasi toksin uremia (ureum dan kreatinin) dalam darah yang dapat membahayakan kelangsungan hidup pasien (Sudoyo dkk, 2006).

Sindrom GGK merupakan permasalahan bidang nefrologi dengan angka kejadian yang masih tinggi, etiologi luas dan komplek, sering tanpa keluhan maupun gejala klinik kecuali sudah terjun ke stadium terminal (gagal ginjal terminal) (Sudoyo dkk, 2006). Menurut Budiyanto (2002) kegagalan ginjal dikarenakan kerusakan ginjal ditandai dengan gejala adanya protein dalam urin (proteinuria atau albuminuria), darah dalam urin (hematuria) dan kenaikan tingkat ureum atau kreatinin (sisa produksi metabolisme protein) dalam darah. Hemodialisis atau cuci darah dilakukan dengan tujuan untuk membuang hasil metabolisme dan cairan yang tidak dapat dikeluarkan dari tubuh karena ginjal gagal menjalankan fungsinya. Hemodialisis dapat dilakukan untuk mencegah komplikasi gagal ginjal yang serius. Hemodialisis akan memperbaiki abnormalitas biokimia, menyebabkan cairan, protein dan natrium dapat dikonsumsi secara bebas, 
menghilangkan

perdarahan dan

kecenderungan membantu

Lampung, Pasien Rutin HD selama minimal 1 bulan, Bersedia menjadi responden. Sedangkan Kriteria Ekslusi: Pasien GGK yang tidak menjalani hemodialisa, Pasien GGK yang tidak menjalani hemodialisa rutin, Tidak mengkonsumsi obat-obatan yang dapat meningkatkan kadar asam urat dalam serum seperti alkohol, asam askorbit, aspirin dosis rendah, kafein, cisplatin, diazoxide, diuretik, epinefrin, ethambutol, levodopa, metal-dopa, asam nikotinat, fenotiazin, dan theofilin. Tidak mengkonsumsi obat-obatan yang menurunkan kadar asam urat dalam serum seperti alopurinol, aspirin dosis tinggi, azathioprin, clofibrat, kortikosteroid, estrogen, infuse glucose, guafenisin, manitol, probenecid, dan warfarin.

\section{Hasil Penelitian}

\section{Karakteristik Subjek Penelitian Berdasarkan Umur, Jenis Kelamin, Pendidikan Dan Pekerjaan}

Distribusi umur, jenis kelamin, pendidikan dan pekerjaan Pasien Penyakit Ginjal Kronik yang menjalani

Hemoldialisis Di Rumah Sakit Pertamina Bintang Amin terlihat pada table 4.1 dibawah ini:

Tabel 4.1 Karakteristik Responden menurut Umur, Jenis Kelamin,Pendidikan Dan Pekerjaan

\begin{tabular}{ccc}
\hline \multicolumn{1}{c}{ Karakteristik } & Frekuensi (n) & Persentase (\%) \\
\hline Umur & & \\
$-\quad$ 30-39 Tahun & 2 & 5.9 \\
- 40-49 Tahun & 10 & 29.4 \\
- 50-59 Tahun & 13 & 38.2 \\
- 60-69 Tahun & 7 & 20.6 \\
- 70-79 Tahun & 2 & 5.9 \\
Jenis Kelamin & & \\
- Laki-laki & 15 & 44.1 \\
- Perempuan & 19 & 55.9 \\
Pendidikan & & \\
- Tidak Sekolah & 2 & 5.9 \\
- SD & 3 & 8.8 \\
- SMP & 5 & 14.7 \\
- SMA & 14 & 41.2 \\
- PT & 10 & 29.4 \\
Pekerjaan & & 23.5 \\
- Tidak bekerja & 8 & 11.8 \\
- Ibu Rumah Tangga & 4 & 23.5 \\
- PNS & 8 & 11.8 \\
- Wiraswasta & 4 & 8.8 \\
- Buruh & 3 & 11.8 \\
- Petani & 4 & 100,0 \\
- Swasta & 3 & \\
\hline
\end{tabular}


Berdasarkan tabel 4.1 di atas menunjukkan distribusi frekuensi berdasarkan umur menunjukkan sebagian besar responden berumur 5059 Tahun yaitu sebanyak 13 responden $(38.2 \%)$, jenis kelamin yang paling

Analisis Univariat

Kadar Creatinin

Tabel 4.2Kadar Kreatinin pada pasien gagal ginjal kronik yang menjalani hemodialisa di Rumah Sakit Pertamina Bintang Amin Bandar Lampung Tahun 2016

\begin{tabular}{ccccc}
\hline Variabel & Mean & SD & Min-Mak & 95\% CI \\
\hline Kadar Kreatinin & 2,85 & 0,89 & $1,2-4,7$ & $2,54-3,16$
\end{tabular}

Hasil analisis didapatkan rata-rata Kadar Kreatinin pada pasien gagal ginjal kronik yang menjalani hemodialisa adalah 2,85mg/dl, dengan SD 0,89 $\mathrm{mg} / \mathrm{dl}$. Kadar kreatinin terendah adalah $1,2 \mathrm{mg} / \mathrm{dl}$ dan yang tertinggi adalah 4.7 banyak adalah perempuan yaitu 19 responden (55.9\%), berpendidikan SMA yaitu 14 responden $(41.2 \%)$, tidak bekerja dan bekerja sebagai PNS masing-masing sebanyak 8 responden $(23.5 \%)$.

\section{Kadar Asam Urat}

Tabel 4.3Kadar Asam Urat pada pasien gagal ginjal kronik yang menjalani hemodialisa di Rumah Sakit Pertamina Bintang Amin Bandar Lampung Tahun 2016

\begin{tabular}{lcccc}
\hline \multicolumn{1}{c}{ Variabel } & Mean & SD & Min-Mak & $\mathbf{9 5 \%}$ CI \\
\hline $\begin{array}{l}\text { Kadar Asam } \\
\text { Urat }\end{array}$ & 7,49 & 1,34 & $4,5-10,7$ & $7,03-7,96$ \\
\hline
\end{tabular}

Hasil analisis didapatkan rata-rata kadar asam urat pada pasien gagal ginjal kronik yang menjalani hemodialisa adalah $7,49 \mathrm{mg} / \mathrm{dl}$, dengan SD 1,34 $\mathrm{mg} / \mathrm{dl}$. Kadar asam urat terendah adalah $\mathrm{mg} / \mathrm{dl}$. Hasil estimasi interval dapat disimpulkan bahwa 95\% diyakini bahwa rata-rata Nilai Kadar Kreatinin responden adalah antara 2,54 $-3,16$ $\mathrm{mg} / \mathrm{dl}$.

\section{Analisis Bivariat}

$4,5 \mathrm{mg} / \mathrm{dl}$ dan yang tertinggi adalah $10.7 \mathrm{mg} / \mathrm{dl}$. Hasil estimasi interval dapat disimpulkan bahwa 95\% diyakini bahwa rata-rata kadar asam urat responden adalah antara $7,03-7,96 \mathrm{mg} / \mathrm{dl}$

Tabel 4.4Hasil Uji Korelasi Spearman Kadar Asam Urat dengan Kadar Kreatinin pada pasien gagal ginjal kronik yang menjalani hemodialisa di Rumah Sakit Pertamina Bintang Amin Bandar Lampung Tahun 2016

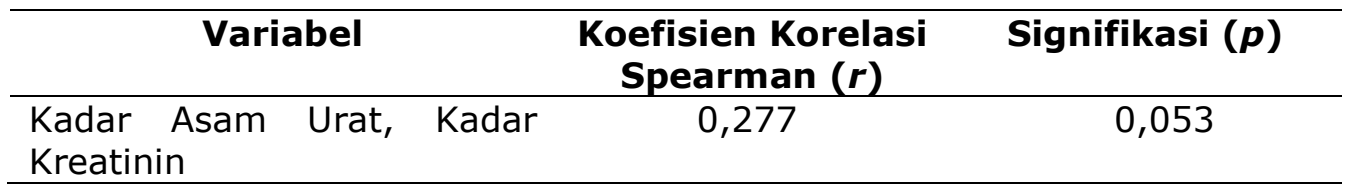


Hasil uji Korelasi Spearman didapatkan nilai $p$ sebesar 0,053 dan nilai $r$ sebesar 0,277 . Karena nilai $p=0,053>0,05$ sehingga dapat disimpulkan tidak ada hubungan Kadar Asam Urat dengan Kadar Kreatinin pada pasien gagal ginjal kronik yang menjalani hemodialisa di Rumah Sakit Pertamina Bintang Amin Bandar Lampung Tahun 2016.

\section{Pembahasan}

Berdasarkan tabel 4.1 di atas menunjukkan distribusi frekuensi berdasarkan umur menunjukkan sebagian besar responden berumur 5059 Tahun yaitu sebanyak 13 responden $(38.2 \%)$, jenis kelamin yang paling banyak adalah perempuan yaitu 19 responden $(55.9 \%)$, berpendidikan SMA yaitu 14 responden (41.2\%), tidak bekerja dan bekerja sebagai PNS masing-masing sebanyak 8 responden (23.5\%).

Berdasarkan tabel 4.2 terlihat hasil analisis didapatkan rata-rata Kadar Kreatinin pada pasien gagal ginjal kronik yang menjalani hemodialisa adalah $2,85 \mathrm{mg} / \mathrm{dl}$, dengan SD 0,89 $\mathrm{mg} / \mathrm{dl}$. Kadar kreatinin terendah adalah 1,2 $\mathrm{mg} / \mathrm{dl}$ dan yang tertinggi adalah 4.7 $\mathrm{mg} / \mathrm{dl}$. Hasil estimasi interval dapat disimpulkan bahwa 95\% diyakini bahwa rata-rata Nilai Kadar Kreatinin responden adalah antara 2,54 -3,16 $\mathrm{mg} / \mathrm{dl}$.

Kreatinin adalah produk protein otot yang merupakan hasil akhir metabolisme otot yang dilepaskan dari otot dengan kecepatan yang hampir konstan dan diekskresi dalam urin dengan kecepatan yang sama. Kreatinin diekskresikan oleh ginjal melalui kombinasi filtrasi dan sekresi, konsentrasinya relatif konstan dalam plasma dari hari ke hari, kadar yang lebih besar dari nilai normal mengisyaratkan adanya gangguan fungsi ginjal (Corwin J.E, 2001).

Peningkatan dua kali lipat kadar kreatinin serum mengindikasikan adanya penurunan fungsi ginjal sebesar $50 \%$, demikian juga peningkatan kadar kreatinin tiga kali lipat mengisyaratkan penurunan fungsi ginjal sebesar $75 \%$ (Soeparman dkk, 2001).
Hasil penelitian ini sejalan dengan penelitian Alfonso tahun 2016 tentang Gambaran kadar kreatinin serum pada pasien penyakit ginjal kronik stadium 5 non dialysis yang menunjukkan terdapat 35 pasien yang terdiagnosis penyakit ginjal kronik stadium 5 non dialysis mengalami peningkatan kadar kreatinin serum $(100 \%)$.

Berdasarkan tabel 4.3 terlihat hasil analisis didapatkan rata-rata kadar asam urat pada pasien gagal ginjal kronik yang menjalani hemodialisa adalah 7,49mg/dl, dengan SD 1,34 $\mathrm{mg} / \mathrm{dl}$. Kadar asam urat terendah adalah $4,5 \mathrm{mg} / \mathrm{dl}$ dan yang tertinggi adalah $10.7 \mathrm{mg} / \mathrm{dl}$. Hasil estimasi interval dapat disimpulkan bahwa 95\% diyakini bahwa rata-rata kadar asam urat responden adalah antara 7,03-7,96 mg/dl.

Kadar asam urat pada tiap individu sangat bervariasi tergantung pada sintesis dan ekskresinya. Hiperurisemia terjadi bila kadar asam urat melebihi daya larutnya dalam plasma yaitu 6,7 $\mathrm{mg} / \mathrm{dL}$ pada suhu $37^{\circ} \mathrm{C}$. Kondisi ini dapat disebabkan karena ketidakseimbangan antara produksi yang berlebihan, penurunan ekskresi atau gabungan keduanya. Produksi yang berlebihan terjadi pada keadaan diet tinggi purin, alkoholisme, turn over nukleotida yang meningkat, obesitas, dan dislipidemia. Sedangkan penurunan ekskresi asam urat terjadi pada penyakit ginjal, hipertensi, penggunaan diuretik, resistensi insulin, dan kadar estrogen yang rendah (Johnson et al., 2003; Berry et al., 2004; Hediger et al., 2005).

Pada manifestasi sindrom gout mencakup atritis gout yang akut (serangan rekuren inflamasi artikuler dan periartikuler yang berat), tofus (endapan Kristal yang menumpuk dalam jaringan artikuler, jaringan oseus, jaringan lunak serta kartilago), nefropati gout (gangguan ginjal) dan pembentukkan batu asam urat dalam traktus urinarius. Ada empat stadium penyakit gout yang dikenal: hiperurisemia asimtomatik, arthritis gout yang kronis, gout interkritikal dan gout tofeseus yang kronik (Doherty, 2009).

Hasil penelitian ini sejalan dengan penelitian Mubarokah (2013) tentang 
Perbedaan Kadar Hemoglobin, Ureum, Kreatinin Pre Dan Post Hemodialisa Selama 3 Bulan Menjalani Hemodialisa Di RSUD Raden Mattaher Jambi Periode Desember 2012 - Maret 2013, yang menunjukkan rata-rata kadar ureum penderita GGK sebelum hemodialisa sebesar $134.745 \mathrm{mg} / \mathrm{dl}$ (Mubarok, 2013).

Berdasarkan tabel 4.4 terlihat hasil penelitian menunjukkan tidak ada hubungan Kadar Asam Urat dengan Kadar Kreatinin pada pasien gagal ginjal kronik yang menjalani hemodialisa di Rumah Sakit Pertamina Bintang Amin Bandar Lampung Tahun 2016 ( p value 0,053).

Kreatinin dalam urin berasal dari filtrasi glomerulus dan sekresi oleh tubulus proksimal ginjal. Berat molekulnya kecil sehingga dapat secara bebas masuk dalam filtrat glomerulus. Kreatinin yang diekskresi dalam urin terutama berasal dari metabolisme kreatinin dalam otot sehingga jumlah kreatinin dalam urin mencerminkan massa otot tubuh dan relatif stabil pada individu sehat (Levey, 2003; Remer et al. 2002; Henry, 2001).

Ginjal memiliki peran penting untuk mempertahankan stabilitas volume, komposisi elektrolit, dan osmolaritas cairan ekstraseluler. Salah satu fungsi penting ginjal lainnya adalah untuk mengekskresikan produk-produk akhir atau sisa metabolisme tubuh, misalnya urea, asam urat, dan kreatinin. Apabila sisa metabolisme tubuh tersebut dibiarkan menumpuk, zat tersebut bisa menjadi racun bagi tubuh, terutama ginjal. Gagal Ginjal Kronik (GGK) adalah kemunduran dari kemampuan ginjal dalam membersihkan darah dari bahanbahan racun, yang menyebabkan penimbunan limbah metabolik didalam darah (Suryawan, 2016).

Hasil metabolit seperti ureum dan kreatinin akan meningkat. Bila fungsi ginjal hanya $5 \%$ atau kurang, maka pengobatan cuci darah atau cangkok ginjal mutlak diperlukan. Kadar ureum dan kreatinin serum ini perlu dimonitor sebagai indikator kerusakan ginjal dan pemeriksaan ini dilakukan setiap akan menjalani terapi hemodialisis, seringkali terlihat bahwa kadar ureum dan kreatinin serum pasien yang akan menjalani terapi hemodialisis kadarnya berubah-ubah, bahkan melebihi kadar normal (Suryawan, 2016).

Dalam penelitian ini diperoleh responden dengan kadar asam urat normal ( $<6,5 \mathrm{mg} / \mathrm{dl}$ pada wanita dan $7,5 \mathrm{mg} / \mathrm{dl}$ pada laki-laki) namun memiliki kadar creatinin yang tinggi yaitu $>1,2 \mathrm{mg} / \mathrm{dl}$, hal ini dapat disebabkan karena konsumsi obatobatan tertentu oleh responden seperti Obat - obatan yang dapat meningkatkan kadar kreatinin: amfotericin $B$, androgen, asam askorbat, barbiturat, captopril, sefalosporin, cimetidine, clonidine, kortikosteroid, dextran, doksisiklin, fruktosa, gentamisin, glukosa, hidralazin, levodopa, lithium, mannitol, metildopa, propanolol, sulfonamide, streptokinase, testosterone, trimethoprim. Dan sebalinya terdapat responden dengan kadar kreatinin tidak terlalu tinggi namun kadar asam uratnya tinggi, hal tersebut dapat disebabkan karena responden mengkonsumsi obat-obatan yang dapat meningkatkan kadar asam urat dalam serum seperti alkhol, asam askorbit, aspirin dosis rendah, kafein, cisplatin, diazoxide, diuretik, epinefrin, ethambutol, levodopa, metal-dopa, asam nikotinat, fenotiazin, dan theofilin.

\section{KESIMPULAN}

1. Hasil analisis didapatkan rata-rata Kadar Kreatinin pada pasien gagal ginjal kronik yang menjalani hemodialisa adalah $2,85 \mathrm{mg} / \mathrm{dl}$, dengan SD 0,89 mg/dl.

2. Hasil analisis didapatkan rata-rata kadar asam urat pada pasien gagal ginjal kronik yang menjalani hemodialisa adalah $7,49 \mathrm{mg} / \mathrm{dl}$, dengan SD 1,34 mg/dl.

3. Tidak ada hubungan Kadar Asam Urat dengan Kadar Kreatinin pada pasien gagal ginjal kronik yang menjalani hemodialisa di Rumah Sakit Pertamina Bintang Amin Bandar Lampung Tahun 2016.

\section{DAFTAR PUSTAKA}

Berry CE and JM Hare (2004). Xanthine Oxidoreductase and Cardiovascular Disease: Molecular Mechanism and 
Pathophysiological Implications. Am J Physiol : 589-606

Budiyanto, M.A.K., (2002), Dasar-dasar Ilmu Gizi, Malang: UMM Press. Hal. 149.

Corwin, E. J. (2001). Patofisiologi. Jakarta: EGC. Depkes RI

Daugirdas, J, T.,Blake, P, G.,\& Ing, T, S. (2007) Handbook Of Dialysis $4^{\text {th }}$ Edition. Philadelphia. Lippincott Williams \& Wilkins

Hastono. (2007) Analisa Data Kesehatan. Jakarta : FKM. UI

Hediger MA, Johnson RJ, Miyazaki $H$, EndouH (2005). Molecular Physiology of Urate Transport. Am J Physiol :125-33

Henry's. Basic Examination of Urine in Clinical Diagnosis and Management by Laboratory Methods. Twenty- first Edition $2007: 397$

Johnson RJ, Kang DH, Feig D, Kivlighn S, Kannelis J, Watanabe S, Tuttle KR (2003). Is there a pathogenetic role for uric acid in hypertension and cardiovascular and renal disease? Hypertension, 41:11831190

Lamb E, Newman JD and Price PC, 'Kidney Function Test' in Tietz Textbook of Clinical Chemistry and Molecular Diagnostic, eds. Burtis C, Ashwood RE and Bruns ED, fourth edition, Elseiver Saunders, 2006, p803-5.

Levey AS, Coresh J, Balk E, Kausz AT, Levin A, Steffes MW, et.al. National Kidney Foundation Practise Guidelines for Chronic Kidney Disease : Evaluation, Classification, and Stratification. An Intern Med 2003 : 139 : 137 47

Mubarok (2013) Perbedaan Kadar Hemoglobin, Ureum, Kreatinin Pre Dan Post Hemodialisa Selama
3 Bulan Menjalani Hemodialisa Di RSUD Raden Mattaher Jambi Periode Desember 2012 - Maret 2013.

National Kidney Foundation I, KidneyDialysis Outcome Quality Initiative. K/DOQI clinical practice guidelines : anemia. Am J Kidney Dis $2001 ; 37$

National Kidney Foundation, 2002. Definition and stages of chronic kidney disease. New York: National Kidney Foundation.

Notoatmodjo, S. 2010. Metodologi Penelitian Kesehatan. Jakarta : Rineka Cipta

Riset Kesehatan Dasar (Riskesdas) tahun 2013

Sherwood, Lauralee. 2012. Fisiologi Manusia dari Sel ke Sistem.Edisi 6. Jakarta. EGC.

Silbernagl, S. and Lang F.,2012. Teks\& Atlas Berwarna Patofisiologi. Jakarta : EGC

Soeparman, dkk. 2001. Ilmu Penyakit Dalam Jilid II. Jakarta : Balai Penerbit FKUI

Sudoyo, Aru W, Setiyohadi, Alwi, Simadibrata, dkk, 2006, Buku Ajar Ilmu Penyakit Dalam, Penerbit Departemen Ilmu Penyakit Dalam Fakultas Kedokteran Universitas Indonesia: Jakarta

Suhardjono, dkk., 2001. Gagal Ginjal Kronik. Buku Ajar Ilmu Penyakit Dalam. Jilid II. Edisi Ketiga. FK UI, Jakarta

Sukandar. 2006. Gagal Ginjal Dan Panduan Terapi Dialisis. Fakultas Kedokteran UNPAD. Bandung

Wortmann R. L., 2009. Gout dan Gangguan Metabolisme Purin Lain dalam Harrison Prinsip-prinsip IImu penyakit Dalam. Edisi 13. Jakarta : ECG. Hal.2300-2309 